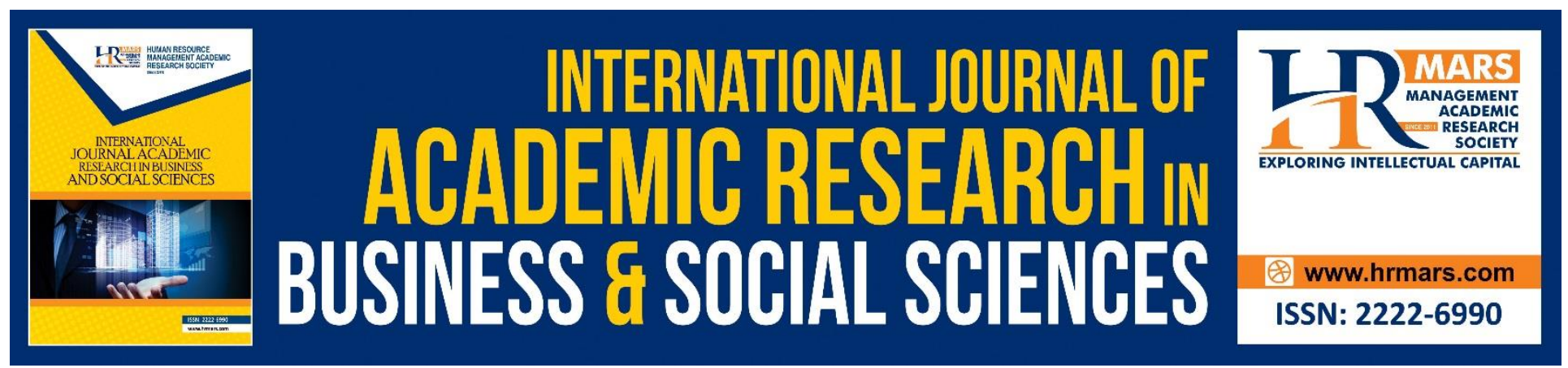

\title{
The Effect of Tax Audit Using the Computer on Tax Non- Compliance in Palestine
}

\author{
Majed Alshrouf
}

To Link this Article: http://dx.doi.org/10.6007/IJARBSS/v9-i3/5678

DOI: $\quad 10.6007 /$ IJARBSS/v9-i3/5678

Received: 19 Feb 2019, Revised: 26 March 2019, Accepted: 06 April 2019

Published Online: 12 April 2019

In-Text Citation: (Alshrouf, 2019)

To Cite this Article: Alshrouf, M. (2019). The Effect of Tax Audit Using the Computer on Tax Non-Compliance in Palestine. International Journal of Academic Research in Business and Social Sciences, 9(3), 296-304.

\section{Copyright: (C) 2019 The Author(s)}

Published by Human Resource Management Academic Research Society (www.hrmars.com)

This article is published under the Creative Commons Attribution (CC BY 4.0) license. Anyone may reproduce, distribute, translate and create derivative works of this article (for both commercial and non-commercial purposes), subject to full attribution to the original publication and authors. The full terms of this license may be seen at: http://creativecommons.org/licences/by/4.0/legalcode

Vol. 9, No. 3, 2019, Pg. 296 - 304

Full Terms \& Conditions of access and use can be found at http://hrmars.com/index.php/pages/detail/publication-ethics 


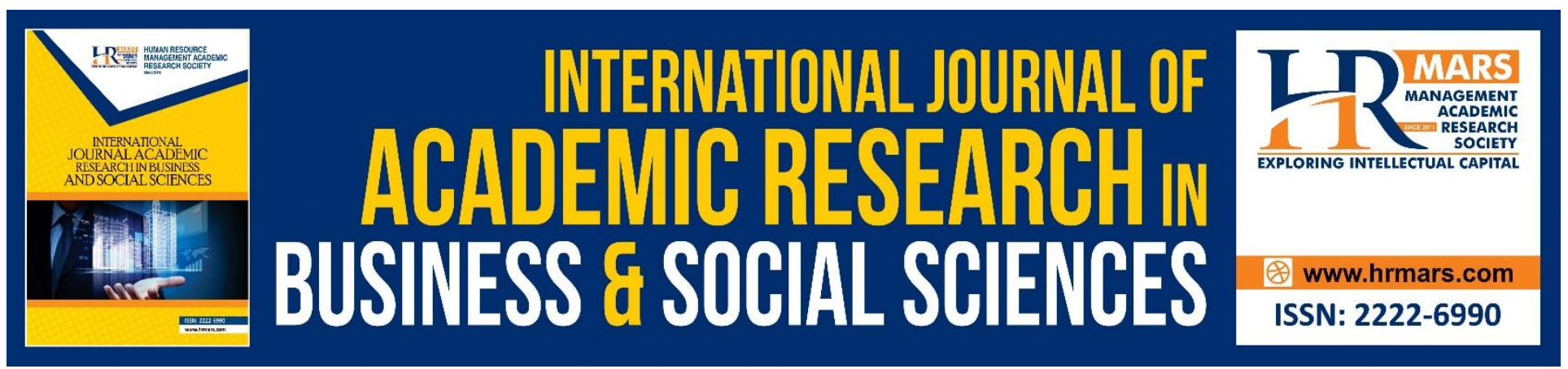

\title{
The Effect of Tax Audit Using the Computer on Tax Non-Compliance in Palestine
}

\author{
Majed Alshrouf \\ Department of Accounting, Palestine Ahliya University, Palestine \\ Email:majed@paluniv.edu.ps
}

\begin{abstract}
Across the world issues of non-compliance to tax obligations remains a challenge to policy makers. The knowledge of what influences compliance to tax obligations can serve as a guide to control this challenge. Base of this premise, the current study focuses on the objective to include the role of tax audit on the behaviour of non-compliance to tax among the Palestinians taxpayers. This study is conceived on the basis of an exhaustive review of literature. Giving rise to the development of a conceptual model discussed in this study. The outcome of the earlier studies that assessed the relationship between tax audit and tax non-compliance have been highly inconsistent. In view of this, the proposed conceptual framework encompasses an exceptional and all-inclusive model that is expected to improve the existing knowledge as well as guide stakeholders to better comprehend the influence of tax audit on non-compliance to tax. Furthermore, considering the fact that the hypothesized model for this study was founded on the basis of review of existing literature, there is a need to collect data, analyse the data and come up with an empirical evidence to confirm the proposed relationship.
\end{abstract}

Keywords: Tax Audit, Tax Non-Compliance, Deterrence Theory.

\section{Introduction}

The use of tax revenue by the present government includes infrastructural development and payment for services such as defence, medical care, road constructions, buildings, management of schools, hospitals and providing shelter, food and medical care to the weak and vulnerable such as the poor in the society. This implies financing economic and non-economic activities may not be possible without appropriate taxes, and so also the existence of any government (Aliyu, Alkali, \& Alkali, 2016). Throughout the world tax remains a major source of revenue that has existed as the oldest means of generating funds for continuity of government. Hence, the expenditure requirement of most economies is reliant on taxation (Kira, 2017). Torgler (2005) identified the fact that the amount of tax revenue generated by any government depends on many factors. One of such factors is the willingness of taxpayers to conform with provisions of the tax laws. McGee et al. (2008) 
emphasised the impossibility of achieving a $100 \%$ compliance to tax regulations in any country. Accordingly, Franzoni (2000) stressed that tax non-compliance remains a vital problem for tax administration. This is to say that tax non-compliance has been a primary issue for governments across the world and regulating this behaviour has been daunting task, despite the creative approaches and dynamic schemes being employed to tackle it (Alleyne \& Harris, 2017).

As a developing country, Palestine depends majorly on both tax revenue and international aids for financing projects for the growth and development of the country (Alkhatib and Abdul-Jabbar, 2017). In Palestine, tax non-compliance is at a very high level (Rahhal, 2017). In recent times, the annual loss from Palestinian treasury as a result of tax non-compliance amounts to USD 500 million as estimated by the Coalition for Accountability and Integrity (2018).

The situation of the tax non-compliance in Palestine is very high. This necessitates a thorough assessment of the important factor such as tax audit that could have an effect on tax non-compliance. Tax authorities have stressed the adoption of the computer network-based audit model of tax collection in recent times (Liu, 2011). This point to the positive role the fast developments in information technology have on tax system such as the assessment of tax liability, collection of tax revenues and also the ability of tax administrations' to discover the emergent number of taxable transactions. The current study focuses on, the need tax officials' to improve auditing skills in order to design policies to increase its efficiency in revenue collection and also reduce tax non-compliance.

\section{Literature Review and Hypothesis Development Tax Non-Compliance}

Tax non-compliance refers to the deliberate or non-deliberate refusal of taxpayer's to pay their due taxes (James \& Alley, 2004). This definition of non-compliance encompasses a broader conceptualization by capturing both deliberate and non-deliberate lack of compliance to tax payment. Accordingly, McKerchar (2002) stressed the fact that non-compliance of some taxpayers is not a deliberate act, but rather as a result of issues such as complexity in the tax law. Tax noncompliance is considered a vital challenge to the effective functioning of the government in any country. This is as a result of the fact that it can render a government weak financially and consequently jeopardize the execution of sound economic policies as well as its ability to efficiently provide needed essential products and services to its citizens (Pirttila, 1999).

The wider implication of tax non-compliance includes; fiscal deficits, quest for loans from a different country or financial institutions such as the International Monetary Fund. This will consequently weakens the economic growth of developing economies due to its fragility. Bahl and Bird (2008) according stressed the importance of tax administration over tax itself. This is because tax administration guarantees the maximum feasible compliance of tax payers to tax obligations. The reality is that tax non-compliance is in high practice due to ineffectiveness of tax administration (Brautigam, Fjeldstad, \& Moore, 2008) and across time, there are higher rate of tax non- compliance or tax evasion than tax compliance all over the world.

Tax non-compliance is regarded as a financial crime hence and defaulters are seen as criminals (AlAdham, Abukhadijeh, \& Qasem, 2016). As earlier defined tax non-compliance refers to the deliberate effort by taxpayers to avoid payment of tax obligation as stipulated by tax laws (Brink \& Porcano, 2016). Many studies affirm the fact that revenue losses resulting from tax non-compliance 
INTERNATIONAL JOURNAL OF ACADEMIC RESEARCH IN BUSINESS AND SOCIAL SCIENCES

Vol. 9, No. 3, March, 2019, E-ISSN: 222 2-6990 @ 2019 HRMARS

is higher among developing countries as compared to the developed countries. This is attributed to the high occurrence of the hidden economy (informal sector) in the developed world (Terkper, 2003).

\section{Tax Audit and Tax Non-Compliance}

Tax audit is a measure employed by tax authorities for detecting tax irregularities (Alm, 1991). Tax audit present an effective mechanism for enforcing tax structure in tax policy (Kirchler, Kogler, \& Muehlbacher, 2014). It is of high relevance to perform an audit of the tax collection and management system. This will help to measure its effectiveness, understand the peculiar challenges confronting the tax collection system and also assist management of the tax authorities in promoting their tax governance according to law (Liu, 2011).

According to Nhavira (2016) the taxpayer is faced with two main options, first to declare the actual income accrued to the business and secondly to declare less than the actual income. The study further emphasised that taxpayer's decision on the value of tax to evade is similar to the way the tax payer considers any risky decision or gamble. They consider maximization of expected utility alongside the possible legal tax penalties related to the manner they are affected by other contingent cost. Subsequently, maximising tax compliance is influenced by factors such as the possibility of been detected and penalized, the magnitude of the penalty for non-compliance and the taxpayers' degree of risk repugnance (Slemrod, 2007). The significance of audit factor cannot be overemphasised, as it has received greater attention in both economic and social-psychological models of tax noncompliance (Chau \& Leung, 2009). An audit exercise is a process employed by tax authorities in order to detect tax non-compliance and it also refers to taxpayers' assessment of the likelihood of detection of tax non-compliance.

Based on the economic model, taxpayers are assumed to attempt to maximize the decision to comply by comparing the benefit of successful non-compliance with the risk of being detected and its penalty. The value of tax non-compliance is therefore dependant on the probability of audit and tax penalties. Allingham and Sandmo (1972) subsequently concluded that the higher the probability of detection, the greater the value of income that will be declared. Even though the alternative option of evading all or part of actual income is risky, but more income will be saved if the respective tax file is not audited. Although in the likelihood of an audit exercise, the option of compliance is a better choice considering that the payment of fine will reduce the income even higher than the sincere payment of tax obligations (Kirchler, Muehlbacher, Kastlunger \& Wahl, 2007).

Similar to the work of Christensen and Hite (1997) and Abdul-Jabbar (2009), the present study also considered audit as the perception of the taxpayer about likelihood that an audit will be carried out and its possibility of the audit exercise to detect any irregularities. Theoretically, audit has been analysed to have a significantly negative influence on tax non-compliance (Allingham \& Sandmo, 1972; Kirchler, Hoelzl, \& Wahl, 2008; Weigel, Hessing, \& Elffers, 1987). This theorised relationship between audit and tax non-compliance has been examined by several studies using different methods with a few mixed findings reported, while more of the studies were found to support the theory. Survey studies have also presented supportive evidence on the significantly negative effect of audit on non- compliance, with a single study having an opposing the negative relationship.

A survey carried out to assess tax non-compliance in Australia found that the perception of detection had a significant and negative influence on tax non-compliance (Wenzel, 2004). Focusing on what 
determines corporate SMEs tax non-compliance behaviour, Abdul Jabbar (2009) found that audit has a significant and negative effect on tax non-compliance. These findings conform to the theoretical analysis by Allingham and Sandmo (1972) which stated that, if the perception of taxpayers is that the probability of detection low then logically they will tend towards engaging in tax non-compliance.

On the contrary, a study of the perception of tax consultants in Malaysia by Sapiei and Kasipillai (2013) revealed that the effect was insignificant. This outcome contradicts earlier findings and the theorised relationship and could be attributable to differences in sampled population in the studies. Tax consultants are well informed on the probability of an audit. Therefore, they may under value its impact if it's believed to be low. Pommerehne and Weck-Hannemann (1996) by making a comparison between various Swiss cantons, found that the periods when audit was high, tax compliance was also high in the cantons for those particular observed periods. Chang, Nichols and Schultz (1987) found the relationship to be negative while studying the non-compliance attitude given different levels of audit probabilities. In a similar approach, Beck, Davis and Jung (1991); Alm, Sanchez and De Juan (1995) studied the effect of changes in the audit rates (5\%,30\% and 60\%) on tax compliance and found a negative relationship. Also, Trivedi, Shehata and Lynn (2003) employed a two scale audit probability rate of 0 and $25 \%$; both results were found to confirm the negative and significant effect of audit rate on tax non-compliance.

Slemrod, Blumenthal and Christian (2001) reported an increase in compliance in a study of 1700 taxpayers randomly sampled from Minnesota, the sample were told through a letter that the tax returns about to be filed by the taxpayers will be subjected to close examination. Kleven et al. (2011) in Denmark carried out an analysis of a randomized tax enforcement experiment. For the starting year, a sample of 40,000 was selected from individual income tax filers through a stratified sampling method. From the sample, half selected at random and subjected to a comprehensive audit, the second half were then intentionally left unaudited. In the following year, a letter of "threat-of-audit" was again randomly allotted and dispatched to both groups of the tax filers. The assessment of the comprehensive administrative tax data revealed that previous audits considerably increase selfreported income. This indicates that the tax filer's perception on probability of detection is greatly influenced by their experience about audit. Similarly, the letter on "threat-of-audit" as well had a significant influence on self-reported income, while the magnitude of its effects is positively dependent on the extent of the audit probability expressed in the letter. Extant literature have mostly revealed a negative correlation between tax audit and tax non-compliance (Alkhatib, Abdul-Jabbar \& Marimuthu, 2018; Almunia \& Lopez-Rodriguez, 2018; Ayers, Seidman, \& Towery, 2015; Bott, Cappelen, Sorensen \& Tungodden, 2017; Dubin \& Wilde, 1988; Slemrod et al., 2001; Witte \& Woodbury, 1985).

Contrary to the general findings, Tauchen, Witte and Beron (1993) emphasises that the effect of tax audit and probability of detection on tax non-compliance is weak among high income groups. The outcome additionally concludes that for high income tax payers, the revenue derived from audit could be substantially lower than the deterrent effect of audits of such groups. Another study with a similar finding is the study by Ariel (2012) in Israel where the study reported that the effect of perceived probability of audit and apprehension on tax non-compliance is not significant. Similar to these was also the experimental study by Alm and McKee (2006) which also established the insignificant effect. Consequently, this shows that the findings of extant literature on the relationship 
INTERNATIONAL JOURNAL OF ACADEMIC RESEARCH IN BUSINESS AND SOCIAL SCIENCES

Vol. 9, No. 3, March, 2019, E-ISSN: 222 2-6990 ¿ 2019 HRMARS

between tax audit and tax non-compliance has been inconsistent. As a result of the mix findings the present study proposes as follows:

H1: There is a negative relationship between tax audit and tax non-compliance.

\section{Research Framework}

The model for this study is presented in Figure 1 below; the model is based on the economic Deterrence Theory. The theory proposes that people's behaviour is usually as a result of the expected gains or cost of such behaviour. Consequently the tax compliance model has its foundation from the Deterrence Theory. The theory elucidates on the deterrent effect sanctions and other punitive measures have on illegal behaviour. Also this theory emphasis that humans tendency to crime is based on their evaluation of the differences in the cost and benefit of the crime, instead of their perception on the variation in motivational factors. This implies an individual is regarded as a rational being who constantly seeks the means of maximizing expected utility from his actions or inactions.

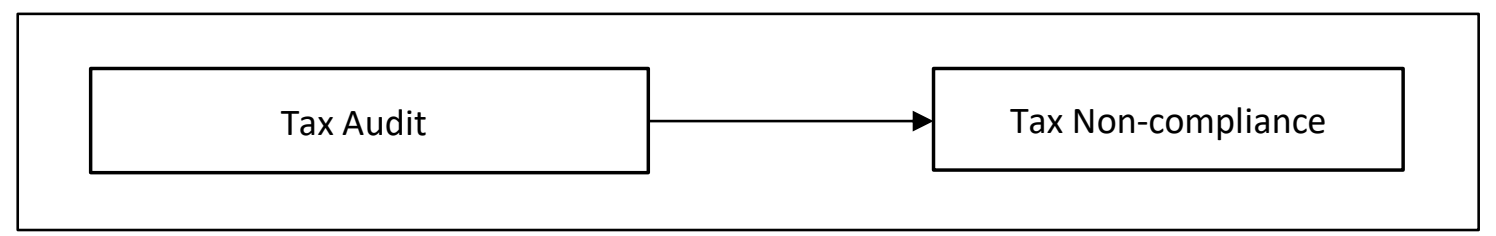

Figure 1: Research Model

\section{Conclusion and Suggestion for Future Study}

Based on the review it can be concluded that tax non-compliance is a global phenomenon and all societies and economic systems across developed and developing countries of the world faces this challenge. Although several factors have been presented as responsible for tax non-compliance, the issue of tax audit has been established by logical and several empirical studies as a major important factor relating to tax non-compliance. Furthermore, in relation to predictors of tax non-compliance, studies on the relationship between the tax audit and tax non-compliance is either scantly or inconsistent. The present study present a review of extant literature on the tax audit and tax noncompliance based on Deterrence Theory. Regardless of the number of existing studies as discussed above, there is a need for more studies to help in better understanding of the subject matter and develop a good understanding of the fundamentally complex subject for the purpose of controlling tax non-compliance. Future approaches should involve the gradual use of taxation information system by the tax authorities. This will facilitate the operation featured network connection among the tax authorities and industry and commerce, banking, customs, foreign trade and other departments. This is because the use of computer-aided audit tools is found to be more convenient and effective. This paper will serve as a guide to stakeholders in the proper comprehension of the effect tax audit has on tax non-compliance, although the proposed model for this study was founded base on review of earlier published research, the study can be made more robust by going further into data collection and analysis of such data for the purpose of providing empirical backing for the study. 
INTERNATIONAL JOURNAL OF ACADEMIC RESEARCH IN BUSINESS AND SOCIAL SCIENCES

Vol. 9, No. 3, March, 2019, E-ISSN: 222 2-6990 @ 2019 HRMARS

\section{References}

Abdul-Jabbar, H. (2009). Income tax non-compliance of small and medium enterprises in Malaysia: Determinants and tax compliance costs. (Unpublished doctoral dissertation). Curtin University of Technology, Perth, Australia.

AlAdham, M., Abukhadijeh, M. A., \& Qasem, M. F. (2016). Tax evasion and tax awareness evidence from Jordan. International Business Research, 9(12), 65-75.

Aliyu, A. A., Alkali, M. Y., \& Alkali, I. (2016). Islamic perspective on the impact of ethics and tax for Nigerian economic development. International Journal of Islamic Economics and Finance Studies, 2(3), 137-150.

Alkhatib, A, A., \& Abdul-Jabbar, H. (2017). An Economic Framework for Tax Evasion in Palestine. American-Eurasian Journal of Scientific Research, 12(6), 300-304.

Alkhatib, A., Abdul-Jabbar, H., Marimuthu, M. (2018). The effects of deterrence factors on income tax evasion among Palestinian SMEs. International Journal of Academic Research in Accounting, Finance and Management Sciences 8 (4), 144-152.

Alleyne, P., \& Harris, T. (2017). Antecedents of taxpayers' intentions to engage in tax evasion: Evidence from Barbados. Journal of Financial Reporting and Accounting, 15(1), 2-21.

Allingham, M., \& Sandmo, A. (1972). Income tax evasion: A theoretical analysis. Journal of Public Economics, 1(3-4), 323-338.

Alm, J. (1991). A perspective on the experimental analysis of taxpayer reporting. The Accounting Review, 66(3), 577-593.

Alm, J., \& McKee, M. (2006). Audit certainty, audit productivity and taxpayers compliance. National Tax Journal, 59(4), 801-816.

Alm, J., Sanchez, I., \& De Juan, A. (1995). Economic and noneconomic factors in tax compliance. Kyklos, 48(1), 1-18.

Almunia, M., \& Lopez-Rodriguez, D. (2018). Under the radar: The effects of monitoring firms on tax compliance. American Economic Journal: Economic Policy, 10(1), 1-38.

Ariel, B. (2012). Deterrence and moral persuasion effects on corporate tax compliance: Findings from a randomized controlled trial. American Society of Criminology, 50(1), 27-69.

Ayers, B. C., Seidman, J. K., \& Towery, E. M. (2015). Taxpayer behavior under audit certainty. Paper presented at IRS-TPC Research Conference. University of Georgia, Athens, USA.

Bahl, R. W., \& Bird, R. M. (2008). Tax policy in developing countries: Looking back and forward. National Tax Journal, 61(2), 279-301.

Beck, P. J., Davis, J. S., \& Jung, W. (1991). Experimental evidence reporting on taxpayer under uncertainty. The Accounting Review, 66(3), 535-558.

Bott, K. M., Cappelen, A. W., Sorensen, E., \& Tungodden, B. (2017). You've got mail: A randomised field experiment on tax evasion. (Working Paper No. 10/2017). Norwegian School of Economics, Bergen, Norway.

Brautigam, D., Fjeldstad, O.-H., \& Moore, M. (2008). Taxation and state-building in developing countries: Capacity and consent. Cambridge, United Kingdom: Cambridge University Press.

Brink, W. D., \& Porcano, T. M. (2016). The impact of culture and economic structure on tax morale and tax evasion: A country-level analysis using SEM. Advances in Taxation, 23(12), 87-123.

Chang, O. H., Nichols, D. R., \& Schultz, J. J. (1987). Taxpayer attitudes toward tax audit risk. Journal of 
INTERNATIONAL JOURNAL OF ACADEMIC RESEARCH IN BUSINESS AND SOCIAL SCIENCES

Vol. 9, No. 3, March, 2019, E-ISSN: 222 2-6990 @ 2019 HRMARS

Economic Psychology, 8(3), 299-309.

Chau, G., \& Leung, P. (2009). A critical review of Fischer tax compliance model: A research synthesis. Journal of Accounting and Taxation, 1(2), 34-40.

Christensen, A. L., \& Hite, P. A. (1997). A study of the effect of taxpayer risk perceptions on ambiguous compliance decisions. Journal of the American Taxation Association, 19(1), 1-18.

Coalition for Accountability and Integrity. (2018, April 23). USD 500 million losses of tax evasion in Palestine (in Arabic). Life Press. Retrieved from http://www.hayatweb.com/ breaking/143106

Dubin, J. A., \& Wilde, L. L. (1988). An empirical analysis of federal income tax auditing and compliance. National Tax Journal, 41(1), 61-74.

Franzoni, L. A. (2000). Tax evasion and tax compliance. The Economics of Public and Tax Law, 4(1), 52-94.

James, S., \& Alley, C. (2004). Tax compliance, self-assessment and tax administration. Journal of Finance and Management in Public Services, 2(2), 27-42.

Kira, A. R. (2017). An evaluation of goverments' initiatives in enhancing small taxpayers' voluntary tax compliance in developing countries. International Journal of Academic Research in Accounting, Finance and Management Sciences, 7(1), 253-267.

Kirchler, E., Hoelzl, E., \& Wahl, I. (2008). Enforced versus voluntary tax compliance: The "slippery slope" framework. Journal of Economic Psychology, 29(2), 210-225.

Kirchler, E., Kogler, C., \& Muehlbacher, S. (2014). Cooperative tax compliance: From deterrence to deference. Current Directions in Psychological Science, 23(2), 87-92.

Kirchler, E., Muehlbacher, S., Kastlunger, B., \& Wahl, I. (2007). Why pay taxes? A review of tax compliance decisions. (Working Paper, No. 07-30). Andrew Young School of Policy Studies, Georgia State University, USA.

Kleven, H. J., Knudsen, M. B., Kreiner, C. T., Pedersen, S., \& Saez, E. (2011). Unwilling or unable to cheat? Evidence from a randomized tax audit experiment in Denmark. The Econometric Society, 79(3), 651-692.

Liu, R. (2011). The application of computer-aided audit for tax collection and management. Procedia Environmental Sciences, 11, 50-54.

McGee, R. W., Ho, S. S. M., \& Li, A. Y. S. (2008). A comparative study on perceived ethics of tax evasion: Hong Kong vs the United States. Journal of Business Ethics, 77(2), 147-158.

McKerchar, M. (2002). The effects of complexity on unintentional noncompliance for personal taxpayers in Australia. Australian Tax Forum, 17(1), 3-26.

Nhavira, J. D. G. (2016). A survey of attitudes to tax evasion by part-time business studies students at the University of Zimbabwe. The Science Probe, 4(1), 10-22.

Pirttila, J. (1999). Tax evasion and economies in transition: Lessons from tax theory. (Working Paper, No. 2). Bank of Finland Institute for Economies In Transition, Helsinki, Finland.

Pommerehne, W. W., \& Weck-Hannemann, H. (1996). Tax rates, tax administration and income tax evasion in Switzerland. Public Choice, 88(1/2), 161-170.

Rahhal, A. I. (2017). Effectiveness of Palestinian income tax rates in facing tax evasion. Global Journal of Engineering Science and Research Management, 4(1), 8-14.

Sapiei, N. S., \& Kasipillai, J. (2013). External tax professionals' views on compliance behaviour of 
corporation. American Journal of Economics, 3(2), 82-89.

Slemrod, J. (2007). Cheating ourselves: The economics of tax evasion. Journal of Economic Perspectives, 21(1), 25-48.

Slemrod, J., Blumenthal, M., \& Christian, K. W. (2001). Taxpayer response to increased probability of audit: Evidence from a controlled experiment in Minnesota. Journal of Public Economic, 79(3), 455-483.

Tauchen, H., Witte, A., \& Beron, K. (1993). Tax compliance: An investigation using individual taxpayer compliance measurement program (TCMP) data. Journal of Quantitative Criminology, 9(2), 177-202.

Terkper, S. (2003). Managing small and medium-size taxpayers in developing economies. Tax Notes International, 29(2), 211-229.

Torgler, B. (2005). Tax morale in Latin America. Public Choice, 122(1/2), 133-157.

Trivedi, V. U., Shehata, M., \& Lynn, B. (2003). Impact of personal and situational factors on taxpayer compliance: An experimental analysis. Journal of Business Ethics, 47(3), 175-197.

Weigel, R. H., Hessing, D. J., \& Elffers, H. (1987). Tax evasion research: A critical appraisal and theoretical model. Journal of Economic Psychology, 8(2), 215-235.

Wenzel, M. (2004). The social side of sanctions: Personal and social norms as moderators of deterrence. Law and Human Behavior, 28(5), 547-567.

Witte, A. D., \& Woodbury, D. F. (1985). The effect of tax laws and tax administration on tax compliance: The case of US individual tax. National Tax Journal, 38(1), 1-13. 